\title{
KASIH FONDASI KELUARGA YANG SEHAT
}

\author{
Agung Gunawan
}

\begin{abstract}
Abstraksi: Keluarga Kristen dipanggil untuk menjadi terang dan garam dunia. Melalui keluarga Kristen diharapkan banyak keluarga-keluarga yang tidak percaya bisa melihat kesaksian hidup dari keluarga Kristen yang baik dan mau percaya kepada Tuhan Yesus. Namun banyak keluarga Kristen yang gagal menjadi terang dan garam dunia, bahkan cenderung menjadi batu sandungan bagi masyarakat sekitar keluarga Kristen berada.
\end{abstract}

Realita menunjukkan bahwa saat ini banyak keluarga yang tidak sehat sehingga tidak mampu menjadi terang dan garam dunia. Banyak keluarga-keluarga Kristen yang tidak harmonis dan bahagia. Akibatnya angka perceraian di kalangan keluarga Kristen semakin hari semakin meningkat tajam. Apa yang menyebabkan banyak keluarga Kristen tidak sehat sehingga menjadi rapuh dan mudah mengalami kehancuran? Hal ini disebabkan karena banyak keluarga Kristen dibangun di atas dasar yang tidak kokoh.

Untuk menciptakan keluarga yang sehat, maka keluarga Kristen harus dibangun di atas fondasi yang kuat. Banyak keluarga Krsiten yang rapuh karena dibangun di atas "materi". Fondasi yang kokoh untuk membangun keluarga Kristen adalah kasih agape. Tanpa fondasi kasih, maka keluarga akan rapuh dan mudah hancur. Kasih tidak hanya sekadar kata-kata semata tapi harus diwujudnyatakan dalam perbuatan sehari-hari. Kasih harus selalu mendasari hidup keluarga Kristen agar menjadi keluarga Kristen yang sehat dan akan membawa dampak bagi gereja sehingga gereja mampu menjadi terang dan garam dalam dunia ini. 
Kata-kata Kunci: Keluarga Sehat, Gereja Sehat, Fondasi Keluarga, Kasih Agape

Abstract: Christian families are called to be the light and salt of the world. Through the Christian families, it is hoped that many unbelieving families can see the witness of life from a good Christian family and they want to believe in the Lord Jesus. But many Christian families fail to become the light and salt of the world, and even tend to be a stumbling block for the communities around which Christian families are located.

Reality shows that today many families are not healthy so that they are unable to become the light and salt of the world. Many Christian families are out of harmony and happy. As a result, divorce rates among Christian families are increasing sharply. What causes many unhealthy Christian families to become fragile and prone to destruction? This is because many Christian families are built on a solid foundation.

To create a healthy family, a Christian family must be built on a strong foundation. Many Christian families are fragile because they are built on "material". The solid foundation for building a Christian family is Agape love. Without a foundation of love, the family will be fragile and easily destroyed. Love is not just mere words but must be manifested in daily actions. Love must always underlies the life of a Christian family in order to become a healthy Christian family that will have an impact on a healthy church so that the church is able to become light and salt in this world.

Keywords: Healthy Family, Healthy Church, Family Foundation, Agape Love 


\section{PENDAHULUAN}

Gereja dan keluarga merupakan dua institusi yang tidak bisa dipisahkan. Gereja dipanggil untuk menjadi terang dan garam dunia. Keluarga-keluarga Kristen yang ada di dalam gereja memiliki peran yang sangat penting untuk mencapai panggilan gereja tersebut. Apabila gereja ingin menjadi terang dan garam, maka gereja harus sehat. Gereja yang sehat adalah gereja yang di dalamnya berisi keluarga-keluarga yang sehat.

Namun fakta menunjukkan bahwa banyak gereja yang gagal menjadi terang dan garam karena keluarga-keluarga yang ada di dalam gereja adalah keluarga-keluarga yang tidak sehat. Keluarga yang tidak sehat akan dapat membawa keluarga menuju kepada kehancuran. Angka perceraian dari keluarga-keluarga Kristen semakin hari semakin meningkat. Perceraiaan dialami oleh kaum rohaniawan, aktivis hingga jemaat biasa dalam gereja. Perceraian (divorce) sebenarnya dapat dibagi ke dalam dua kategori, yaitu perceraian secara legal (legally divorce) dan perceraian secara psikologis (psychological divorce). Perceraian secara legal adalah perceraian yang dilakukan oleh suami istri secara hukum yang disahkan melalui lembaga pengadilan. Setelah diputuskan oleh hakim bahwa perceraian pasangan suami istri dikabulkan, maka mereka akan hidup terpisah baik secara fisik maupun psikis.

Perceraian secara psikologis adalah "perceraian" suami istri yang tidak dilakukan secara hukum di pengadilan dan mereka tidak hidup berpisah satu dengan yang lain, namun sebenarnya secara psikologis mereka sebenarnya bercerai. Banyak pasangan suami istri yang masih tinggal bersama dalam satu atap namun mereka seperti orang yang tidak saling mengenal. Suami istri tidak lagi saling berbicara, tidak mau saling memandang, bahkan tidak mau saling bersentuhan. Kondisi seperti ini menunjukkan bahwa di 
dalam kehidupan suami istri tidak ada lagi ikatan kasih. Kalau sudah demikian, maka di dalam kehidupan suami istri tiap hari terjadi percekcokan dan pertengkaran yang menyebabkan tidak ada lagi damai dan ketentraman di dalam keluarga. Meskipun dalam kondisi yang demikian, ada pasangan suami istri yang tidak mau mengambil langkah hukum untuk melakukan melakukan gugatan perceraian secara legal karena mereka tahu dan takut bahwa perceraian adalah perbuatan dosa di hadapan Tuhan.

Selain daripada itu, ada sebagian keluarga Kristen, yang tidak ingin keluarganya menjadi batu sandungan bagi keluarga lain dengan perceraian mereka. Mereka mencoba menutupi ketidakharmonisan dan ketidakbahagiaan keluarga mereka. Banyak keluarga Kristen berupaya dan berusaha untuk menampilkan diri sedemikian rupa untuk menunjukkan kepada orang lain bahwa keluarga mereka tidak ada masalah. Namun sebenarnya apa yang terjadi sangat bertolak belakang dengan apa yang diperlihatkan di depan umum. Banyak pasangan suami istri yang menggunakan topeng untuk menutupi apa yang sebenarnya terjadi di dalam kehidupan keluarga mereka. Apa yang nampak di luar sangat amat sungguh berbeda jauh dengan apa yang sebenarnya terjadi di dalam keluarga mereka. Inilah yang disebut dengan perceraian secara psikologis. Ini adalah realita dan kondisi yang sangat menyedihkan, memprihatinkan bahkan mengerikan yang dialami oleh keluargakeluarga Kristen. Apabila gereja terdiri dari keluarga-keluarga yang demikian, maka gereja akan gagal untuk mencapai misinya yaitu menjadi terang dan garam dunia. 


\section{Kasih adalah Fondasi Keluarga yang Sehat ${ }^{1}$}

Fondasi adalah sesuatu yang sangat vital bagi sebuah bangunan. Apabila fondasinya kuat, maka bangunan yang dibangun di atasnya pun akan kuat dan kokoh. Sebaliknya apabila fondasinya tidak kuat, maka bangunan yang akan dibangun di atasnya pun akan rapuh dan berbahaya karena cepat atau lambat bangunan yang dibangun suatu hari akan roboh.

Demikian halnya di dalam membangun sebuah keluarga. Sebuah keluarga yang dibangun di atas fondasi yang kuat, ketika menghadapi hantaman angin ribut ataupun bahkan ketika terjadi gempa bumi sekalipun di dalam kehidupan keluarganya, keluarga itu akan kuat bertahan. Sebaliknya sebuah pernikahan dibangun di atas fondasi yang tidak kokoh, ketika datang sedikit hempasan angin persoalan di dalam hidup, keluarga yang dibangun akan roboh dan mengalami kehancuran. Oleh sebab itu, fondasi yang kuat dan kokoh harus dimiliki oleh pasangan yang akan membangun sebuah keluarga yang sehat sehingga akan tahan uji terhadap segala macam bencana di dalam kehidupan ini.

Fondasi yang kokoh itu tidak lain dan tidak bukan adalah KASIH. Kasih di sini adalah bukan kasih Eros (hawa nafsu) yang seringkali dipakai oleh pasangan muda-mudi untuk membangun relasi keintiman di antara mereka. Kasih eros adalah kasih yang sangat egoistis dan rapuh. Kasih eros adalah kasih yang mencari kepuasan dan kesenangan diri sendiri. Ketika apa yang diharapkan tidak terpenuhi, maka pertengkaran dan percekcokan akan menghiasi hari-hari di dalam kehidupan cinta mereka. Akibatnya hubungan mereka akan terganggu dan kalau terus berlanjut, maka

\footnotetext{
${ }^{1}$ Garry Chapman, The Five Languages (Chicago: Norhfield Publishing, 1995), 11-19.
} 
akan berakibat fatal yaitu hancurnya hubungan yang telah mereka jalin selama ini.

Sebagaimana Allah yang mendirikan institusi pernikahan adalah Allah yang Mahakasih, maka keluarga Kristen harus didirikan di atas dasar kasih. ${ }^{2}$ Kasih yang dibutuhkan oleh pasangan suami istri untuk dipakai sebagai fondasi untuk membangun keluarga yang sehat oleh Tuhan adalah Kasih agape (kasih ilahi). Dengan memiliki kasih agape, maka fondasi pernikahan akan menjadi kuat dan kokoh yang pada gilirannya keluarga yang dibangun di atasnya pun akan kuat dan kokoh pula. Kasih agape adalah kasih yang tidak egois tapi justru sebaliknya menempatkan kepentingan pasangannya di atas kepentingan dirinya sendiri. Kasih agape adalah kasih yang memberikan kebahagiaan yang tertinggi bagi pasangannya. Kasih agape adalah kasih yang tanpa pamrih. Kasih agape adalah kasih yang tidak membalas kejahatan dengan kejahatan tapi membalas kejahatan dengan kebaikan. Kasih agape adalah kasih yang rela berkorban bagi pasangannya walaupun pasangannya dianggap sudah tidak layak untuk mendapatkannya. Apabila pernikahan dibangun di atas fondasi kasih agape ini, maka akan dapat dijamin bahwa keluarga yang akan dibangun akan menjadi keluarga yang sehat dan kuat. Keluarga Kristen yang sehat akan dapat menjadi berkat, terang, dan saksi bagi keluarga-keluarga yang lain.

\section{Manifestasi Kasih ${ }^{3}$}

Kasih agape bukanlah sekadar kata-kata tapi harus diwujudnyatakan di dalam perbuatan dalam kehidupan sehari-hari.

\footnotetext{
${ }^{2}$ Al Janssen, Your Marriage Masterpiece (Colorado: Focus on the Family, 2001), 81-91.

${ }^{3} 1$ Korintus 13:4-7.
} 
Adapun bukti dan manifestasi dari kasih agape adalah seperti yang ditulis oleh Firman Tuhan di dalam surat Paulus kepada jemaat di Korintus.

\section{Kasih Itu Sabar}

Kata "sabar" di sini mengandung pengertian mau menerima keberadaan orang lain. Suami istri harus belajar untuk menerima pasangannya apa adanya. Suami istri harus menerima kekurangan dari pasangannya. Pasangan suami istri juga harus belajar menerima kelebihan dari pasangannnya. Selain daripada itu, pasangan suami istri juga harus menerima perbedaan di antara mereka.

Tuhan menjadikan laki-laki dan perempuan berbeda bukan hanya secara fisik tetapi banyak hal yang berbeda antara kaum lakilaki dan kaum perempuan. Perbedaan sifat, kebiasaan, kecenderungan, keinginan, dan masih banyak perbedaan yang lainnya. ${ }^{4}$ Saling menerima merupakan wujud kasih yaitu kesabaran terhadap pasangannya.

Belajar untuk saling menerima memang tidaklah mudah. Kegagalan untuk menerima dengan penuh kesabaran pasangannya acapkali menjadi penyebab ketidakharmonisan dalam kehidupan keluarga yang akan dapat mengganggu kekokohan sebuah keluarga. Oleh sebab itu, pasangan suami istri harus sabar seorang terhadap yang lain artinya bersedia dengan tulus menerima pasangannya apa adanya.

\footnotetext{
${ }^{4}$ John Gray, Men Are from Mars, Women Are from Venus (New York: HarperCollins Publisher, 1992), 9-14.
} 


\section{Kasih Itu Murah Hati}

Istilah "murah hati" artinya mau memahami kesalahan orang lain. Pasangan suami istri yang memiliki kemurahan hati tidak akan terlalu cepat menghakimi pasangannya apabila pasangannya melakukan kekeliruan atau kesalahan. Tidak ada seorang pun yang sempurna di dalam dunia ini. Setiap orang pasti bisa melakukan kesalahan. Demikian pula pasangan suami istri di dalam sebuah keluarga. Oleh sebab itu, sikap murah hati harus dikembangkan di dalam kehidupan pasangan suami istri.

Untuk dapat mengembangkan sikap murah hati, maka suami atau istri perlu menanyakan dengan kasih kepada pasangannya mengapa ia melakukan kesalahan atau kekeliruan yang demikian. Dengan mengetahui dan memahami apa yang melatarbelakangi sikap dan tindakan pasangan yang salah atau keliru tersebut, suami atau istri tidak akan cepat menghakimi, dan kemudian menghukum pasangannya yang melakukan kesalahan. ${ }^{5}$

Salah satu kunci untuk bisa memiliki kemurahan hati adalah komunikasi yang lancar dan sehat antara suami istri. ${ }^{6}$ Komunikasi yang sehat sangat dibutuhkan untuk dapat menumbuhkan sifat murah hati. Oleh sebab itu, komunikasi suami istri perlu dilatih dan dipraktikkan di dalam kehidupan suami istri agar kemurahan hati dapat dimiliki oleh mereka yang merupakan wujud nyata dari kasih agape. Sifat "murah hati” ini harus ditanamkan dan ditumbuhkan di dalam diri pasangan suami istri.

\footnotetext{
${ }^{5}$ Willard F. Harley, Jr., Give and Take: The Secret to Marital Compatibility (Grand Rapids: Fleming H. Revell, 2000), 55-68.

${ }^{6}$ Cleveland McDonald, Creating A Succesful Marriage (Grand Rapids, MI.: Baker Book House, 1992), 51-52.
} 


\section{Kasih Tidak Cemburu}

Kata "tidak cemburu" di sini bukan menjelaskan tentang kecemburuan seseorang terhadap pasangannya yang memiliki hubungan dengan laki-laki atau perempuan lain. Cemburu seperti itu bisa dibenarkan apabila tidak dilakukan secara berlebihan. Cemburu yang tepat dan beralasan adalah salah satu bukti daripada cinta seseorang terhadap pasangannya. Sedangkan cemburu yang kurang tepat dan berlebihan justru merupakan tanda kebencian bukan cinta seseorang terhadap pasangannya.

"Tidak Cemburu" (not envy) di sini berbicara tentang tidak iri hati atas keberhasilan dan kelebihan pasangannya. Seorang suami atau istri tidak boleh merasa iri hati terhadap pasangannya yang mungkin lebih pandai, lebih mampu bekerja, dan lebih banyak menghasilkan uang, lebih banyak teman, dan lain-lain. Perasaan iri hati bisa menimbulkan malapetaka bagi keberlangsungan kehidupan sebuah keluarga. Di mana ada iri hati di situ akan muncul kebencian yang pada gilirannya akan membawa kepada tindakan yang merusak, menjatuhkan, menghancurkan bahkan tidak segan-segan membunuh pasangannya. Di dalam keluarga yang sehat kata "cemburu" atau lebih tepatnya "iri hati" tidak boleh ada di dalam kamus kehidupan suami istri. ${ }^{7}$

\section{Kasih Tidak Memegahkan Diri}

"Memegahkan diri" di sini mengandung pengertian memandang rendah pasangannya. Seseorang cenderung memandang rendah pasangan yang mungkin memiliki latar belakang yang kurang dibandingkan dengan dirinya, baik dalam hal

\footnotetext{
${ }^{7}$ Howard Markman, Fighting for Your Marriage (San Francisco: Josse-Press Publisher, 1990), 13-34.
} 
pendidikan, ekonomi maupun status sosial. Ia merasa dirinya lebih superior terhadap pasangannya. Memandang rendah pasangan dapat terlihat dengan bagaimana ia berbicara secara kasar terhadap pasangannya, bagaimana ia memperlakukan pasangan bukan seperti suami atau istri namun seperti pembantu, serta ia menganggap bahwa pasanganya tidak layak untuk dilibatkan di dalam mengambil keputusan di dalam keluarga.

Firman Tuhan mengatakan bahwa suami istri adalah dua menjadi satu artinya bahwa tidak ada lagi perbedaan di antara mereka. Mereka sekarang adalah setara dan sederajat di dalam keluarga terlepas dari apa dan bagaimana latar belakangnya. Oleh sebab itu, sikap "memegahkan diri" yang ditunjukkan dengan memandang rendah pasangannya adalah bertentangan dengan Firman Tuhan dan tidak boleh terjadi di dalam keluarga yang sehat. ${ }^{8}$

\section{Kasih Tidak Sombong}

Kata "tidak sombong" di sini mengandung pengertian yang agak berbeda dengan "memegahkan diri". Kata "sombong" di sini menjelaskan tentang sikap seseorang yang menganggap bahwa semua apa yang ia miliki baik harta maupun kesuksesan hanya karena hasil dari usaha dia seorang diri. Ia menganggap bahwa pasangannya tidak memiliki andil sama sekali di dalam keberhasilan yang dicapainya.

Suami atau istri tidak boleh merasa dan menganggap bahwa keberhasilan yang ia capai tidak ada kaitan sama sekali dengan pasangannya. Suami atau istri tidak boleh menganggap bahwa ia berhasil karena hasil jerih payahnya atau kerja kerasnya sendiri

\footnotetext{
${ }^{8}$ McDonald, Creating A Succesful Marriage, 69-73.
} 
tanpa mau mengakui peran serta dari pasangannya. Hal ini tidak boleh terjadi di dalam sebuah keluarga yang diberkati Tuhan karena pada hakekatnya suami istri tidak bisa terpisah antara satu dengan yang lain. Menyadari bahwa istri diciptakan dari tulang rusuk laki-laki, maka suami istri saling melengkapi dan saling mengisi. Oleh sebab itu, keberhasilan seorang suami adalah juga berkat dukungan dari istrinya dan sebaliknya kesuksesan istri adalah juga karena adanya topangan dari suaminya. Jadi kesombongan harus dikikis habis di dalam diri suami atau istri yang ingin memiliki keluarga yang sehat. ${ }^{9}$

\section{Kasih Tidak Melakukan yang Tidak Sopan}

Suami istri yang memiliki kasih agape harus dibuktikan dengan tidak melakukan hal-hal yang tidak sopan atau lebih tepatnya menghindari dan membuang tindakan dan atau kata-kata kasar terhadap pasangannya. ${ }^{10}$

Tindakan kasar biasanya dilakukan oleh kaum laki-laki terhadap istrinya sebagai bentuk pelampiasan kemarahan. Hari ini banyak terjadi kekerasan dalam rumah tangga (KDRT) yang dilakukan oleh para suami yang menyebabkan banyak korban para istri dan anak-anak. Mereka banyak yang mengalami luka fisik maupun luka batin atas kekerasan yang dilakukan oleh suami atau papa mereka. Oleh karena itu, seorang suami harus bisa menahan diri agar tidak menyakiti dan melukai pasangannya sebagai bukti dari kasih agape.

Selain tindakan kasar ada juga kata-kata kasar yang biasanya dilakukan oleh kaum perempuan terhadap suami atau anak-anaknya sebagai wujud kejengkelan dan kekecewaan yang ia alami. Ucapan

\footnotetext{
${ }^{9}$ Markman, Fighting for Your Marriage, 145.

${ }^{10}$ McDonald, Creating A Succesful Marriage, 186-188.
} 
yang kasar bisa seperti mata pisau yang dapat menyakiti, melukai hati, dan perasaan suami serta anak-anaknya. Banyak suami dan anak yang tidak betah tinggal di dalam rumah karena istrinya atau mamanya tidak mampu menjaga lidahnya. Oleh sebab itu, seorang istri harus bisa mengendalikan lidahnya agar jangan melukai pasangannya dengan kata-kata yang kasar dan menyakitkan.

Tindakan dan kata-kata yang kasar sangat besar dampaknya bagi kehidupan dan keharmonisan sebuah rumah tangga. Oleh sebab itu, kekasaran (rude) baik oleh suami atau istri harus dibuang jauh-jauh di dalam kehidupan keluarga yang diberkati Tuhan di mana suami dapat menjaga kaki dan tangannya, dan istri menjaga mulutnya untuk tidak menyakiti pasangannya.

\section{Kasih Tidak Mencari Keuntungan Diri Sendiri}

Suami istri yang saling mengasihi dengan kasih agape harus belajar untuk tidak mencari keuntungan atau kesenangan diri sendiri namun berusaha untuk mengembangkan sikap untuk mau menguntungkan dan menyenangkan pasangannya dengan cara saling menghormati dan menghargai pasangannya. ${ }^{11}$ Sikap suami istri yang saling menghormati dan menghargai terbukti sangat ampuh di dalam menghindari penyelewengan dan perselingkuhan di dalam sebuah keluarga. Bentuk penghormatan dan penghargaan bagi perempuan dan laki-laki berbeda. Bagi kaum perempuan, ia merasa dihormati dan dihargai kalau pasangannya memberi pujian terhadap karyanya dan penampilannya.

Berbeda dengan kaum perempuan, seorang laki-laki akan merasa dihormati dan dihargai apabila pasangannya selalu menunjukkan sikap bahwa ia membutuhkan suaminya. Perlu

${ }^{11}$ McDonald, Creating A Succesful Marriage, 141-143. 
diketahui oleh kaum perempuan bahwa apabila seorang laki-laki merasa dibutuhkan, maka harga dirinya akan terangkat dan ia akan bangga terhadap dirinya. Apabila seorang suami merasa dibutuhkan oleh istrinya, maka ia merasa dihargai dan dihormati oleh istrinya. Sebagai responsnya ia akan berusaha semaksimal mungkin untuk menyenangkan dan membahagiakan istrinya. Sebaliknya apabila istri merasa tidak membutuhkan lagi suaminya itu berarti bahwa ia tidak mampu menghargai dan menghormati suaminya. Sebagai akibatnya, maka suami akan cenderung tidak peduli lagi terhadap istri bahkan tidak sedikit suami yang jatuh kedalam pelukan perempuan lain yang dirasakan sangat "membutuhkan" dia. Kalau hal ini terjadi, maka dapatlah dipastikan bahwa keluarga ini tidak akan dapat bertahan lama.

\section{Kasih Tidak Pemarah}

Bukti kasih agape yang harus dimiliki oleh suami atau istri adalah tidak mudah marah terhadap pasangannya. Suami atau istri tidak boleh terlalu mudah marah di dalam merespons ucapan, sikap atau tindakan dari pasangannya yang sebenarnya baik dan positif bagi dia. Di dalam kehidupan sebuah pernikahan, pasangan suami istri yang memiliki kasih Agape tidak boleh terlalu mudah tersinggung dan marah terhadap kritik, nasehat, ataupun teguran pasangannya yang membangun. Salah satu ciri dari pasangan suami istri yang sehat dan kondusif ialah adanya kesediaan dan kemauan masing-masing pribadi untuk menerima dengan penuh kerendahan hati segala macam kritik, nasehat, ataupun teguran dari pasangannya demi kebaikan bersama. Kritik, nasehat, dan teguran harus menjadi bahan introspeksi diri agar segala kekurangan dan kelemahannya dapat diperbaiki demi keharmonisan dan kebahagiaan hubungan suami istri. ${ }^{12}$

${ }^{12}$ Harley F., Jr., Give and Take, 85. 
Tidak ada suami atau istri yang sempurna di dalam setiap kehidupan rumah tangga yang ada di dalam dunia yang telah dirusak oleh dosa ini. Setiap suami atau istri pasti ada kekurangan dan kelemahan yang mungkin tidak disadari oleh dirinya sendiri. Oleh sebab itu, suami atau istri membutuhkan pasangannya untuk mengingatkan dan menyadarkan pasangannya melalui kritikan, teguran, saran ataupun nasehat yang membangun. Namun perlu juga diperhatikan bahwa di dalam menyampaikan kritik, nasehat, ataupun teguran suami atau istri harus melakukannya dengan cara yang benar. Seringkali kritik, nasehat, ataupun teguran yang positif dari suami atau istri direspons secara negatif oleh pasangan karena caranya kurang tepat. Firman Tuhan mengatakan marilah kita saling menasehati dengan kasih yang diwujudkan dengan menggunakan kata-kata atau nada bicara yang tidak menyakiti dan menyinggung pasangannya.

\section{Kasih Tidak Menyimpan Kesalahan Orang Lain}

Suami istri yang mempraktikkan kasih agape tidak boleh menyimpan kesalahan dari pasangannya. Tidak boleh menyimpan kesalahan dari pasangannya berarti suami atau istri tidak menaruh dendam terhadap pasangannya yang mungkin pernah menyakitinya dengan sangat amat luar biasanya hebatnya. Untuk bisa melakukan hal ini dibutuhkan pengampunan. Oleh sebab itu, di dalam kehidupan suami istri pengampunan perlu dan harus dikembangkan. $^{13}$

Mengampuni memang tidaklah mudah bagi mereka yang pernah dikecewakan, dikhianati atau bahkan mungkin disakiti secara luar biasa oleh pasangannya. Namun di dalam kehidupan keluarga Kristen pengampunan bukanlah sebuah pilihan tapi merupakan suatu keharusan. Pengampunan merupakan salah satu

\footnotetext{
${ }^{13}$ Markman, Fighting for Your Marriage, 211-232.
} 
ciri khas dan pilar utama dari kekristenan yang membedakan dengan agama lain. Demikian halnya keluarga Kristen akan dapat tampil beda dan mampu menjadi terang bagi keluarga-keluarga yang ada di dalam dunia yang gelap ini kalau keluarga Kristen tersebut dapat mendemonstrasikan pengampuan di antara suami istri.

\section{Kasih Tidak Bersukacita Karena Ketidakadilan, Tetapi Karena Kebenaran}

Kasih agape di sini harus ditunjukkan oleh suami atau istri dengan tidak bersukacita di atas penderitaan pasangannya. Seorang suami jangan ingin menikmati hidup dan menyenangkan dirinya sendiri di atas penderitaan istrinya. Ada banyak kasus di mana suami-suami hanya menghabiskan uang hasil kerja keras dari istrinya sedangkan ia sendiri tidak mau bekerja. Suami-suami menghabiskan uang istrinya untuk main judi, minum-minuman keras, perta pora, dan lain-lain tanpa mempedulikan kesusahan dan penderitaan istrinya di dalam mencari nafkah. Istrinya seakan dijadikan sapi perahan oleh suaminya. Suami macam ini adalah suami yang tidak bertanggung jawab dan bukan suami yang memiliki kasih agape terhadap istrinya.

Firman Tuhan menegaskan bahwa suami, sebagai kepala keluarga, memiliki kewajiban dan tanggung jawab untuk mencari nafkah untuk memenuhi kebutuhan hidup keluarganya. Jadi yang seharusnya bekerja untuk menghidupi istri dan anak adalah suami bukan istri. Kalaupun ada istri yang bekerja, maka sebenarnya hanya sebatas untuk menambah penghasilan bagi keluarga bukan sebagai pemeran utama. Pemeran utama di dalam pemenuhan kebutuhan finansial keluarga adalah suami. Oleh sebab itu, kalau ada suami tidak bekerja dan menghabiskan uang hasil kerja istrinya, para istri harus berani tegas untuk tidak memenuhi 
permintaan suaminya. Namun apabila suami kemudian melakukan tindakan kekerasan karena apa yang diminta tidak dituruti, maka istri jangan takut untuk melapor kepada pihak yang berwajib agar suaminya itu mempertanggungjawabkan perbuatannya. Bukan karena seorang istri mengasihi suaminya lalu istri harus melindungi pasangannya yang melalaikan tanggung jawabnya sebagai suami bahkan memeras istrinya. Kasih harus diimbangi dengan keadilan. Justru kalau istri tidak berani bersikap tegas terhadap suaminya yang bertindak semena-mena terhadap dirinya itu berarti ia ikut andil di dalam menjerumuskan suaminya.

Sekarang dari sisi istri, seorang istri juga jangan bersenangsenang di atas penderitaan suaminya. Ada banyak istri yang memaksa suaminya untuk memenuhi keinginannya untuk membelikan barang-barang yang mewah dan mahal tanpa mau mengerti kondisi keuangan suaminya. Akibatnya karena suami tidak tahan mendengar omelan dan rengekan istrinya yang terus menerus meminta untuk dipenuhi keinginannya, maka dengan terpaksa suami mengambil atau menggunakan uang yang bukan menjadi haknya dengan melakukan manipulasi dan korupsi. Ketika ketahuan, maka ia dihukum dan menderita di dalam penjara sedangkan istrinya bersenang-senang menikmati barang-barang mewah hasil korupsi suaminya. Sikap seperti ini tidak boleh dipelihara dan ditumbuhkembangkan di dalam keluarga Kristen yang sehat.

\section{Kasih Menutupi Segala Sesuatu}

Kasih agape antara pasangan suami istri harus ditandai dengan selalu saling melindungi pasangannya. Melindungi bukan hanya terhadap gangguan atau serangan dari luar keluarganya. Suami atau istri harus selalu berusaha untuk melindungi pasangannya di dalam pengertian bahwa suami atau istri harus 
selalu menutupi kekurangan dan kelemahan pasangannya dengan tidak menceritakannya kepada orang lain termasuk kepada orang tuanya sekalipun.

Kasih agape di sini harus diwujudkan dengan adanya komitmen antara suami atau istri untuk tidak membeberkan atau mempublikasikan kekurangan dan kelemahan dari pasangannya di depan umum dengan tujuan untuk memperoleh dukungan dari pihak luar. Ketika suami atau istri membuka kejelekan pasangannya kepada orang lain sebenarnya ia membuka aibnya sendiri karena mereka pada hakekatnya adalah satu. Oleh sebab itu, pasangan suami istri di dalam keluarga Kristen yang sehat selalu berusaha untuk melindungi atau menutupi kekurangan pasangannya. $^{14}$

\section{Kasih Percaya Segala Sesuatu}

Kasih agape harus diwujudkan oleh suami istri dengan selalu menumbuhkan rasa saling percaya terhadap pasangannya. ${ }^{15}$ Kepercayaan sangat penting dan dibutuhkan di dalam kehidupan pasangan suami istri yang mendambakan keharmonisan rumah tangga. Ketika di dalam keluarga tidak ada lagi saling percaya, yang ada adalah saling curiga dan saling berprasangka buruk. Ketika rumah tangga diisi oleh kecurigaaan dan prasangka, kehidupan suami istri akan dipenuhi dengan ketegangan bahkan pertengkaran setiap hari. Kalau sudah demikian, maka hidup serasa seperti di dalam neraka. Sebagai akibatnya suami atau istri pasti tidak akan betah tinggal di dalam rumah seperti itu. Alhasil perceraian akan menjadi pilihan pasangan suami istri yang hidup di dalam keluarga yang di dalamnya kepercayaan telah sirna.

\footnotetext{
${ }^{14}$ Harley F., Jr., Give and Take, 69-113.

${ }^{15}$ David and Claudia Arp, Marriage Moments (An Arbor, MI: Servant Publications, 1998), 107-112.
} 
Untuk dapat menciptakan kehidupan yang selalu saling percaya maka pasangan suami istri dituntut untuk bisa dipercaya dan tidak menyalahgunakan kepercayaan yang diberikan oleh pasangannya. Ketika ada pengkhianatan, maka kepercayaan akan ternodai. Oleh sebab itu, dalam keluarga Kristen yang sehat pasangan suami istri harus berupaya untuk mengembangkan dan menumbuhkan serta mempertahankan sikap saling percaya satu dengan yang lain.

\section{Kasih Mengharapkan Segala Sesuatu}

Kasih agape juga harus terwujud di dalam kehidupan suami istri dengan memiliki pengharapan terhadap keluarganya terlepas dari apa dan bagaimana kondisi keluarga yang dijalaninya. Pasangan suami istri yang saling mengasihi harus meyakini bahwa selalu ada pengharapan di tengah hantaman badai kehidupan yang mungkin melanda bahtera kehidupan keluarga mereka. Banyak suami istri yang merasa bahwa rumah tangganya sudah tidak ada harapan untuk diperbaiki lagi karena mereka merasa bahwa pasangannya memiliki hati dan kepala yang keras seperti batu yang tidak mungkin bisa berubah. ${ }^{16}$ Akibatnya mereka menjadi putus asa dan merasa seakan tidak memiliki harapan untuk keluar dari kemelut dan prahara rumah tangga yang mereka alami.

Tuhan yang kita sembah dan yang mendirikan pernikahan adalah Tuhan yang Mahakuasa. Karena Tuhan sendiri yang menciptakan dunia beserta isinya termasuk manusia sehingga Tuhan berdaulat terhadap segala ciptaanya termasuk manusia. Oleh sebab itu, di dalam Tuhan tidak ada yang mustahil. Apapun yang tidak mungkin bagi manusia selalu mungkin bagi Tuhan. Hati dan

\footnotetext{
${ }^{16}$ Al Janssen, Your Marriage Masterpiece (Colorado: Focus on the Family, 2001), 159.
} 
kepala yang keras seperti apapun kalau Tuhan bekerja, maka pasti akan hancur berkeping-keping. Oleh sebab itu, dalam keluarga Kristen yang sehat pasangan suami istri harus selalu memohon pertolongan Tuhan serta memiliki pengharapan yang teguh bagi pemulihan keluarganya.

\section{Kasih Sabar Menanggung Segala Sesuatu}

Akhirnya kasih agape juga harus dinyatakan oleh pasangan suami istri dengan selalu berusaha untuk mempertahankan pernikahannya sampai pada akhirnya. Pasangan suami istri harus belajar untuk dapat menghadapi berbagai macam persoalan di dalam kehidupan keluarga dengan penuh ketabahan. Hidup di dalam dunia tidak akan pernah sepi dengan masalah baik kecil, sedang, ataupun berat. Demikian halnya dengan kehidupan pernikahan baik keluarga Kristen maupun non Kristen. Tuhan tidak pernah menjanjikan bahwa keluarga yang diberkati Tuhan adalah keluarga yang bebas dari hambatan dan masalah. Tetapi justru yang membedakan antara keluarga Kristen dengan non Kristen adalah bagaimana ketika mereka diperhadapkan dengan berbagai macam persoalan di dalam keluarga mereka. Bagi keluarga Kristen ketika ada masalah mereka tetap berupaya untuk mempertahankan keluarganya sampai pada titik darah yang penghabisan. ${ }^{17}$ Sedangkan bagi keluarga non Kristen mereka dengan cepat akan mengakhiri pernikahan mereka ketika masalah menghampiri kehidupan keluarga mereka.

Ada banyak masalah yang dialami oleh pasangan suami istri yang seringkali dapat melunturkan kasih yang mula-mula yang pernah mereka miliki. Masalah keuangan dan kesehatan seringkali menjadi pemicu pudarnya kasih suami atau istri terhadap

${ }^{17}$ David and Claudia Arp, Marriage Moments, 97-104. 
pasangannya. Ketika masalah keuangan melilit kehidupan sebuah keluarga tidak sedikit suami atau istri tidak setia lagi terhadap pasangan dan melirik kepada laki-laki atau perempuan lain yang dianggap bisa memberikan jaminan kesejahteraan hidupnya. Selain daripada itu, ketika suami atau istri tidak berdaya karena terserang penyakit tertentu, maka pasangannya mulai merasa lelah dan enggan untuk menjaga dan merawatnya. Bahkan tidak sedikit yang tega menelantarkan pasangannya dengan begitu saja. Kalau hal ini terjadi, dapatlah dikatakan bahwa sebenarnya kasih tidak pernah ada di dalam kehidupan suami istri. Kasih yang sejati harus teruji dan tersimpan selamanya. Keluarga Kristen yang sehat selalu belajar untuk mempertahankan keutuhan keluarganya, kendati menghadapi berbagai macam persoalan.

\section{SIMPULAN}

Pasangan suami istri harus mau belajar untuk mempraktikkan kasih agape dalam kehidupan keluarga selangkah demi selangkah. Kadang mungkin akan mengalami kegagalan tapi mereka tidak boleh putus asa. Pasangan suami istri harus terus mencoba dan mencoba hingga akhirnya mereka mencapai keberhasilan di dalam menyatakan dan mempraktikkan kasih agape kepada pasangannya. Kasih Agape itu harus timbal balik dan tidak bisa hanya satu pihak saja yang dituntut untuk mempraktikkannya. Benyamin Franklin mengatakan bahwa, "Jika kita ingin dikasihi seseorang, kasihilah dia dan bersikaplah agar layak dikasihi." Kasih agape perlu ditabur, disiram, dan dipupuk agar bertumbuh subur di dalam kehidupan keluarga agar tercipta keluarga yang sehat.

Untuk menciptakan keluarga yang sehat dibutuhkan kemauan untuk mengubah apa yang terlanjur salah dalam membangun sebuah keluarga yang sehat dengan fondasi yang benar yaitu KASIH. Tidak ada kata terlambat bagi keluarga-keluarga yang 
sungguh ingin memiliki keluarga yang sehat asal mau berubah. Memang untuk memulai sesuatu perubahan tidaklah mudah. Hal itu membutuhkan keinginan yang kuat dan kemauan yang serius dari keluarga-keluarga Kristen yang ingin sungguh-sungguh memiliki keluarganya yang sehat.

Apabila semua manifestasi kasih yang telah diuraikan di atas diperhatikan dan dijalankan dengan baik oleh keluarga-keluarga Kristen, maka akan tercipta keluarga yang sehat yang akan membawa dampak yang besar bagi gereja untuk mampu menjadi terang dan garam bagi dunia.

Selain adanya usaha dan kemauan yang kuat dari keluargakeluarga untuk berubah, keluarga-keluarga Kristen juga harus perlu memohon kekuatan Roh Kudus untuk memampukan dan menolong agar keluarganya diubah menjadi keluarga yang sehat dan membawa dampak bagi kesehatan gereja dan akan menjadi terang dan garam bagi masyarakat sekitarnya.

\section{DAFTAR RUJUKAN}

Arp, David and Claudia. Marriage Moments. An Arbor, MI: Servant Publications, 1998.

Baughen, Michael \& Myrtle. Christian Marriage. Grand Rapids: Bakker Book House, 1994.

Chapman, Garry. The Five Languages. Chicago: Norhfield Publishing, 1995.

Gray, John. Men Are From Mars, Women Are from Venus. New York: HarperCollins Publisher, 1992. 
Harley, Willard F, Jr., Give and Take: The secret to Marital Compatibility. Grand Rapids: Fleming H. Revell, 2000.

Hendrix, Harville. Getting The Love You Want. New York: HarperPerennial, 1990.

Janssen, Al. Your Marriage Masterpiece. Colorado: Focus on the Family, 2001.

Mack, Wayne A. Strengthening Your Marriage. New Jersey: R\&R Publishing, 1999.

Markman, Howard. Fighting For Your Marriage. San Francisco: Josse-Press Publisher, 1990.

McDonald, Cleveland. Creating A Succesful Marriage. Grand Rapids, Michigan: Baker Book House, 1992. 